\title{
The Developed Mathematics Learning Tools Which Based on Professional Competency In The Phase of One to One Evaluation For Trigonometry Topic In The Major of Information and Communication Engineering of SMK
}

\author{
$1^{\text {st }}$ Armiati \\ Mathematics Department \\ Universitas Negeri Padang \\ Indonesia \\ armiati@fmipa.unp.ac.id
}

\author{
$2^{\text {nd }}$ Hestu Tansil La`ia \\ Mathematics Department \\ Universitas Negeri Padang \\ Indonesia
}

\begin{abstract}
This article discussed the development of mathematics learning tools related to the ability of the students to solve the problem in mathematics. The study focused on the phase of one to one evaluation. In this phase, we interviewed one mathematics teacher and three students which divided into low, medium and high mathematics ability. The result of interview showed that our developed learning tools were easy to study and it can be used to teach the students. On the other hand, there should be an additional explanation to student worksheet because the students with low and medium ability still need advices to solve the mathematics problem. Overall, our developed student worksheet was able to increase the ability of student to solve any given mathematics problem.
\end{abstract}

Keywords-Lesson plan, student worksheet, professional competency, information and communication engineering, trigonometry

\section{INTRODUCTION}

Vocational High Schools are educational institutions that have a mandate to prepare students to have knowledge and skills so that they are able to work according to their vocational professions. This was stated in Law No. 20, Article 15 of 2003 and Minister of RI Regulation No. 17 Article 76 of 2010. Subsequently in Presidential Instruction No. 9 of 2016 stated that it is necessary to revitalize vocational secondary schools in order to improve the quality and competitiveness of the nation. For this reason, changes in curriculum designs are integrated into character values, High-Level Thinking Skills (HOTS), and 21st century skills. This is done with the hope that graduates of vocational schools will be independent and professional.

A person's independence can be seen from his ability to complete tasks without being dependent on others. An independent person must have competence. Competence is interpreted as mastery of a task, skill, attitude and appreciation that must be possessed and become part of a person, so that he can perform cognitive, affective and psychomotor behaviors as well as possible [4]. While the Profession Word in the Big Indonesian Dictionary is defined as a field of work based on certain skills education (skills, vocational, etc.). Based on this, teachers who teach in vocational schools should provide subject matter to refer to the competencies that vocational school students must have in carrying out their profession later.

In fact, many vocational school students are less fond of mathematics, they think mathematics is a difficult and less useful lesson in their fields of expertise [1]. Based on the research that has been done, this condition occurs because most mathematics teachers in vocational schools provide mathematics material in the same way for all skill programs in vocational schools [1], [2]. This resulted in the mathematics material being taught to be less attractive to vocational students, because they did not see the usefulness of the material for their expertise. Conditions like this still occur to date, this is known based on interviews with vocational school mathematics teachers (September 2017) that the mathematics material provided is guided by the mathematics material contained in general high school mathematics books. The teaching materials that they use so far mostly refer to teaching materials used for public high schools. It may causes the students do not like mathematics since the purpose of general high school education is different from the purpose of education in vocational schools. The constraints experienced by most of the mathematics teachers who teach in vocational schools are the unavailability of mathematics teaching materials that correspond to each vocational school student expertise program.

In connection with this problem, it is necessary to conduct research related to the development of teaching materials that pay attention to the competence and profession of vocational school students. Several studies related to professional competency-based teaching materials have been carried out by [1], [3], [5]. Armiati have developed a professional competency-based mathematics module for vocational technology school students, from the study concluded that problem solving skills, communication skills, student interest and motivation increased after learning to use mathematical modules that linked mathematics material to the student profession [1]. However, with the enactment of the 2013 curriculum learning in vocational schools no longer uses modules so that learning materials need to be developed in accordance 
with the demands of the curriculum. Research conducted by Makhashova and Omarov states that the development of students' competencies is influenced by learning tools that are adapted to the profession in the field of student expertise [3], [5]. This means that learning devices that pay attention to the profession in the field of expertise have a positive impact on vocational school students. Professional competency-based learning devices are learning tools that relate subject matter to the work to be undertaken by students after later graduation, namely learning that links mathematics material taught with student professional problems in accordance with their field of expertise in vocational schools. The main characteristic of professional competence-based learning is that the initial problem for a mathematical material is always associated with problems in the field of student expertise. Furthermore, the problem is directed towards solving it using mathematical concepts. To understand mathematics conceptually, students are also given exercises in the form of questions that do not contain the problem of expertise, this is done so that students are still able to solve mathematical problems in terms of theoretical. In the final section students are again given problems related to the field of expertise and mathematical calculation problems [2]. This article discussed the phase one on one of the research on the development of professional competency-based mathematics learning tools for vocational school students in information and communication engineering expertise. The problem that will be answered is how the responses of the vocational school mathematics teacher and students in the field of information and communication engineering expertise to the professional learning competency-based mathematics learning devices.

\section{Methods}

The method that used in this study was develoment research [6]. The development research consist of 3 stages; preliminary, prototype, and assessment. In the preliminary stage, we analyzed the contex and the needs. In the prototype stage, we developed the product resulted from preliminary study. Prototype production included the activity of designing, developing and formative evaluation. The evaluation stage is an assessment phase to the resulted prototype by using practicality and effectivity tests. In this stage, semi sumative was also applied. Formative evaluation included self evaluation, expert reviews, one to one evaluation, small group evaluation and field test. One to one evaluation is applied to a mathematics teacher, a computer teacher and three students. The students were divided into low, medium and high mathematics ability. The instruments were observation sheet, questionnare and interview guideline. The summary of the stages is provided in Fig. 1.

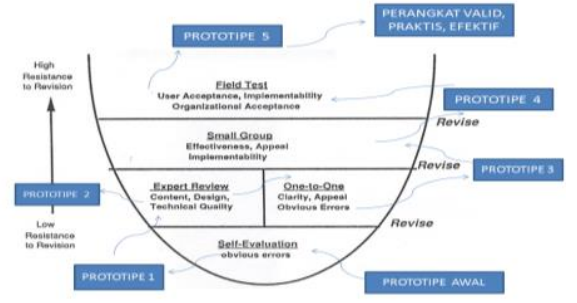

Fig. 1. The stages to develop the learning tools [6]
One to one evaluation was done by giving the instrument of lesson plan and student worksheet to the two teachers; a mathematics and a computer teachers. We asked the mathematics and productive lesson teacher for the correlation of material in the learning tools and in the curriculum, the easiness of understanding of teacher in delivering the lesson. To the students, we provide worksheet to know the problems and to know their opinions about the problems.

\section{RESUlt AND DiscuSSION}

One-on-one evaluation phase is carried out after the device is declared feasible to be used by experts at the expert review stage. The following section presents the results of the evaluation of the device from mathematics teachers, productive subject teachers and vocational school students for eight meetings

\section{The evaluation to mathematics teacher}

In this evaluation activity the mathematics teacher was given a learning design and student worksheets for eight meetings. Based on the results of the teacher's analysis of learning design that has been made, it needs improvement in the preliminary stage. The following is an excerpt for the introduction activities in the learning design.

TABLE I. AN EXCERPT For THE INTRODUCTION ACTIVITIES IN THE LEARNING DESIGN.

\begin{tabular}{|c|c|c|}
\hline $\begin{array}{c}\text { Tahapan } \\
\text { Pembelajaran } \\
\end{array}$ & Deskripsi Aktivitas Pembelajaran Peserta didik & Wakte \\
\hline \multicolumn{3}{|c|}{ Pendahuluan } \\
\hline $\begin{array}{l}\quad \text { Pembukaan: } \\
\text { Salam,Doa, } \\
\text { Menyampaikan } \\
\text { Tujuan } \\
\text { Pembelajaran, dan } \\
\text { motivasi }\end{array}$ & $\begin{array}{l}\text { 1. Peserta didik merespon salam dan tanda syukur } \\
\text { kepada Tuhan dan saling mendoakan(PPK) } \\
\text { 2. Peserta didik perespon saat guru mencek kehadiran } \\
\text { peserta didik (PPK) } \\
\text { 3. Peserta didik memperhatikan dan merespon guru } \\
\text { disaat guru menyemangati peserta didik melalui } \\
\text { pengulasan tujuan peserta didik untuk belajar. } \\
\text { 4. Peserta didik mengulas kembali materi yang lalu } \\
\text { melaui pertanyaan apersepsi yang diberikan guru } \\
\text { 5. Peserta didik menerima informasi tentang "Fungsi } \\
\text { Trigonometr" serta penerapan dalam bidang } \\
\text { keahliannya. } \\
\text { 6. Peserta didik diberi motivasi oleh guru }\end{array}$ & 10 \\
\hline
\end{tabular}

In the introductory section the teacher suggests that each meeting at points 4,5 and 6 should be made clear. Point 4 makes a form of apperception that will be given to students. Point 5 gives a review of the material that has been learned related to the material to be taught. Point 6 write down the form of motivation that will be given. In the core and closing activities in the learning design according to the mathematics teacher is good and easy to understand. Likewise for the student worksheets according to the mathematics teacher the problems presented are in accordance with the mathematics material and will greatly assist students of information and communication technology expertise programs in understanding mathematics.

In the introductory section the teacher suggests that each meeting at points 4,5 and 6 should be made clear. Point 4 makes a form of apperception that will be given to students. Point 5 gives a review of the material that has been learned 
related to the material to be taught. Point 6 write down the form of motivation that will be given. In the core and closing activities in the learning design according to the mathematics teacher is good and easy to understand. Likewise for the student worksheets according to the mathematics teacher the problems presented are in accordance with the mathematics material and will greatly assist students of information and communication technology expertise programs in understanding mathematics.

2. The evaluation to the productive lesson teacher

The designed learning plans and student worksheets are given to a teacher who teaches computer subjects. Through this teacher it is expected to obtain input on the suitability of the problem chosen with the student's area of expertise. Related to the problems given in the learning design according to the teacher in question, it is in accordance with the field of expertise of network engineering and communication students. Based on the analysis of the learning design, the teacher advises on the core activities that the problems contained in the student worksheets are also written in the learning design.

TABle II. An EXAMPLE Display In THE LEARNing DESIGN.

\begin{tabular}{|c|c|}
\hline $\begin{array}{l}\quad \text { Fase II } \\
\text { Mengorganisasikan } \\
\text { peserta didik } \\
\text { belajar }\end{array}$ & $\begin{array}{l}\text { Menanya } \\
\text { 1. Peserta didik mendiskusikan permasalahan dengan } \\
\text { teman sekelompoknya } \\
\text { 2. Peserta didik merumuskan permasalahan pada LKPD } \\
\text { I tentang fungsi ketahanan baterai dan kapasitas } \\
\text { laptop } \\
\text { 3. Peserta didik mendiskusikan rumusan masalah dan } \\
\text { menyusun beberapa pertanyaan dari permsalahan } \\
\text { pada LKPD I. (4C) } \\
\text { Mengumpulkan Informasi/Eksperimen } \\
\text { 4. Peserta didik menuangkan pemahaman kompetensi } \\
\text { profesinya tentang sistem bilangan komputer dari } \\
\text { apa yang pemah ia pelajari. } \\
\text { 5. Peserta didik menyelesaikan permasalahan } \\
\text { berdasarkan pertayaan dan langkah-langkah yang } \\
\text { telah ia tentukan } \\
\text { 6. Peserta didik menyelesaikan permasalahan pada } \\
\text { LKPD I dengan teratur }\end{array}$ \\
\hline
\end{tabular}

In addition the teacher suggested that for homework should also include questions related to the area of expertise of students.

\section{Pekerjaan Rumah (PR)}

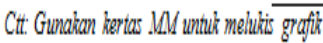

1. Dengan menggunakan tabel perbandingan nilai trigonometri dan selang " $00 \leq x \leq$ $360^{\circ}$ ", lukislah grafik fungsi sinus berikut:
a. $y=2 \sin x^{2}$
b. $y=\sin x+1$
c. $y=\frac{1}{2} \sin x-2$
2. Grafik fungsi trigonometri ditentukan oleh $y=\frac{1}{2} \sin x+2 \sin x$. Lukislah grafik fungsi tersebutpada selang " $-360^{\circ} \leq x \leq 360^{\circ}$ ".

Fig. 2. Homework should also include questions related to the area of expertise of students

Based on suggestions from productive teachers on the next prototype 3 , improvements were made, namely by writing down the problems contained in the student worksheets and adding questions related to the area of expertise in homework.

3. The evaluation to student

At this stage the device tested is the student worksheet. Worksheets tested were 8 meetings. At this stage each student is given a worksheet and told to work on the commands in the worksheet. The following is given the following excerpts in the student worksheet.

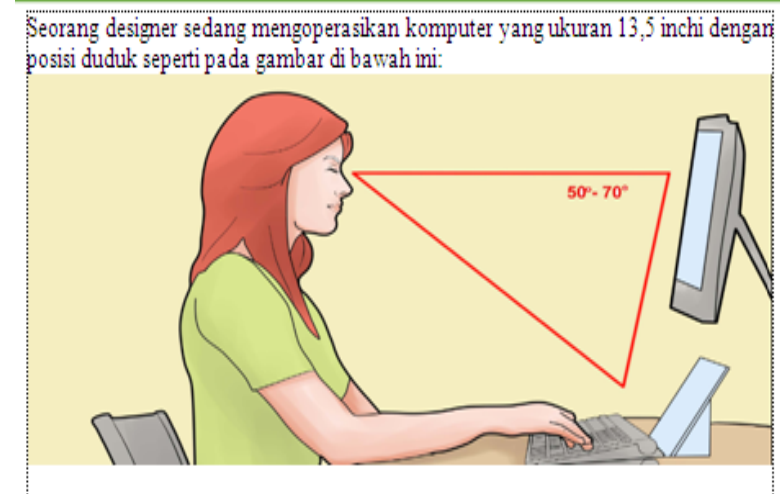

Perhatikanposisi sudut pandang seorang designer tersebut pada monitor. Posisi sudut pandang pada gambar di atas berbentuk segitiga dan ganis pandang mata terhadap: monitor membentuk garis horizontal. Perbandingan jarak pandang mata yang baik terhadap monitor komputer dapat dilihat pada tabel berikut:

Tabel Perbandingan Resolusi Cahava Monitor Komputer

\begin{tabular}{|c|c|c|c|c|}
\hline \multirow{2}{*}{$\begin{array}{l}\text { Clkuran layar } \\
\text { Laptop }\end{array}$} & \multirow{2}{*}{$\begin{array}{c}\text { Jarak } \\
\text { Pandang } \\
\text { Mata }\end{array}$} & \multicolumn{3}{|c|}{$\begin{array}{l}\text { Resolusi cahaya monitor Sudut Posisi Layar Monitor } \\
\text { (Komputer Laptop) }\end{array}$} \\
\hline & & $90^{\circ}<\theta<110^{\circ}$ & $110^{\circ}<\theta<130^{\circ}$ & $\theta \geq 130^{\circ}$ \\
\hline \multirow{3}{*}{$10-12 \mathrm{inch}$} & $20-34 \mathrm{~cm}$ & $20010 x$ & $200.20 x$ & 230 lux \\
\hline & $35-49 \mathrm{~cm}$ & $200.0 x$ & 230.08 & 250.08 \\
\hline & $50-75 \mathrm{~cm}$ & 250.48 & 250.48 & $300.28 x$ \\
\hline \multirow{3}{*}{$13-14$ inch } & $20-34 \mathrm{~cm}$ & $200 \mathrm{lux}$ & $250 \mathrm{lux}$ & $275 \mathrm{lug}$ \\
\hline & $35-49 \mathrm{~cm}$ & $250 \mathrm{lux}$ & $250 \operatorname{lux}$ & $300 \mathrm{lux}$ \\
\hline & $50-75 \mathrm{~cm}$ & $2751 \mathrm{ux}$ & $275 \mathrm{lux}$ & $300 \mathrm{lux}$ \\
\hline \multirow{3}{*}{$15-17$ inch } & $20-34 \mathrm{~cm}$ & $200: 14 x$ & 250.148 & $2751 \mathrm{ux}$ \\
\hline & $35-49 \mathrm{~cm}$ & $200 \mathrm{lux}$ & $250.4 x$ & 300 lux \\
\hline & $50-75 \mathrm{~cm}$ & $275 \mathrm{lux}$ & 300 lux & $300 \mathrm{lux}$ \\
\hline
\end{tabular}

Lukislah bentuk segtiga di atas, dengan titik $A$ berada pada posisi monitor, $B$ berada pada posisimata dan C berada pada posisi keyboard. Jika besar sudut yang dibentuh oleh jarak pandang mata terhadap monitor dan Kevboard (sudut depresi) adalah 30 besar sudut yang dibentuk oleh layar monitor adalah $120^{\circ}$ dan jarak titik antara monito dan keyboard adalah $12 \mathrm{~cm}$. Tentukan jarak pandang mata terhadap monitor dar: berapakah besar resolusi cahaya maksimum dan monitor tersebut?

Fig. 2 An excerpts in the student worksheet.

At the first meeting of high-ability students (T) and low-ability students (R) immediately read and write according to the existing commands, but students with moderate ability (S) after 10 minutes did nothing. The following is a snippet of commands in the student worksheet for meeting 1 . 
1. Apa saja yang telah diketahui pada masalah di atas?

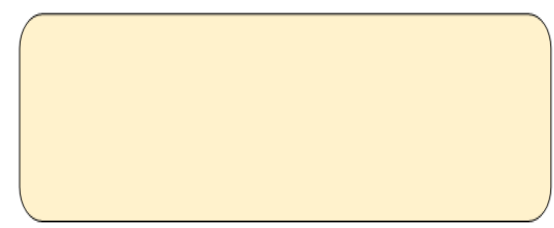

2. Berdasarkan masalah di atas, apa saja informasi yang ananda ketahui berdasarkan pengalaman ananda pada kompetensi profesi yang ananda miliki.

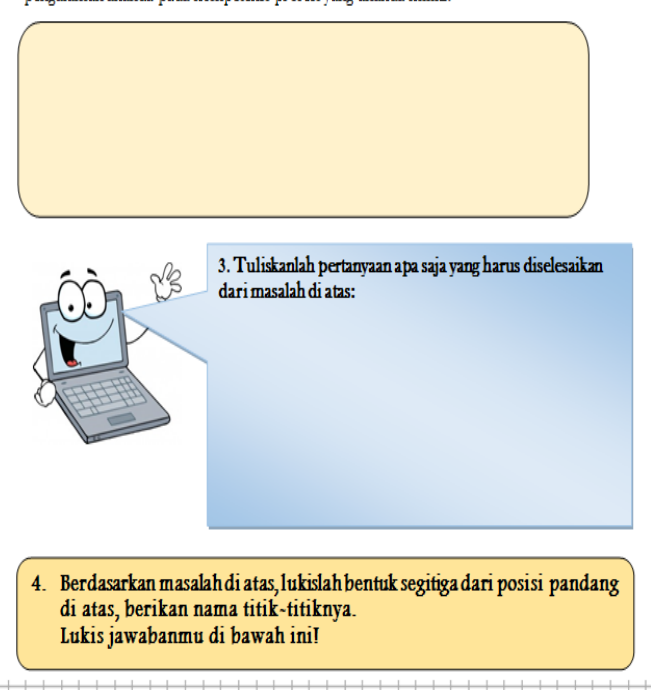

Fig. 3 A snippet of commands in the student worksheet for meeting 1 .

Student $\mathrm{S}$ do not understand the commands in the problem given on the worksheet, after being directed verbally, this student starts writing the commands on the worksheet. Based on the results of the analysis for each student's worksheets that have been done in the one-to-one phase of the work sequence given in the worksheet rather confuses students. Students find it easier to understand commands in worksheets if they are first told to describe the triangle form of the problem. After describing the triangle shape students can answer questions 1-3. So in prototype 3 for several worksheets the order of 4 is made into the first order.

Of the six trials it was noted that $\mathrm{S}$ students always needed help in each worksheet. This is interesting, because based on information from the mathematics teacher, they are classified as a medium group but they were slow. To find out about this, researchers conducted an assessment of student learning outcomes for productive subjects. On the other hand, students $\mathrm{R}$ have a better value than students $\mathrm{S}$. Based on this, it is estimated that student $\mathrm{R}$ is easier to understand the problem provided in the device that has been designed because the problem is related to productive problems that are tailored to the area of expertise. For example, in the problem contained in the interview with $S$ students, the presentation of the problem is related to the body's position when operating the computer. This problem can be solved without the help of student $\mathrm{R}$ who has a better value for the subject matter of expertise, while student $S$ who has less value for his subject matter needs help to answer it. This information indicates that a mathematical learning device that links math problems with the skills of vocational school students can help students understand mathematics more meaningfully and more easily.
Based on observations during the one-on-one phase of the implementation, it was noted that the students were studying the worksheets given. This indicates that devices that link mathematical problems with professional problems make students interested in learning mathematics. From the problems presented, students are always guided to do activities that trigger the development of their problem solving abilities. In this activity, students' problem solving abilities have also increased, because to be able to solve the problems given students must be able to understand the problem, plan solutions, and implement the plans that have been made, examine the results and make conclusions. These steps are indicators of problem solving. Through observation in phase one-on-one, it is known that the presentation of problems associated with the area of expertise helps students understand the problem and make plans where these conditions can train problem-solving skills. Working on the worksheet, after reading the problem, students can follow the directions given in the worksheet, starting from writing down the information, describing the situation from problems into mathematics, and solving problems using mathematical knowledge. But in describing the triangle students are accustomed to using ABC letters, so that if given a picture of a triangle with another name for example $\mathrm{PQR}$ students have difficulty in using formulas. Addressing this problem in a device developed by naming triangles is done using various letters.

\section{CONCLUSIONS}

Based on the analysis of activities in phase one on one it can be concluded that the learning tools that have been designed help students in understanding mathematical material. In general, teachers and students can understand the mathematics material provided through learning plans and student worksheets. The problems given attract and motivate students in solving problems. The activities provided in the worksheet help students in developing problem solving skills, showing mathematical benefits for the field of expertise.

\section{REFERENCES}

[1] Armiati, "Pengembangan Modul Matematika Berbasis Kompetensi Profesi Pada Sekolah menengah Kejuruan Teknologi”, Dirjen PT Depdiknas. Penelitian Hibah Bersaing: FMIPA-UNP, 2008.

[2] Armiati, "Mengembangkan Higher Order of Thinking Skill Siswa Sekolah Menengah Kejuruan Melalui Pembelajaran Matematika Berbasis Kompetensi Profesi. UNP”, Seminar Nasional Matematika Tanggal 21 April 2018 STKIP PGRI Sumbar, Unpublished Jurnal, 2018.

[3] Makhashova. P, "On the Development of Professional Competence

Students of Creative Pedagogical Specialties", International Journal of Environmental \& Science Education, vol. 11, pp. 4660-4668, 2016.

[4] Mulyasa. E, Menjadi Guru Profesional Menciptakan Pembelajaran Kreatif dan Menyenangkan, Bandung: Remaja Rosdakarya, 2005.

[5] Omarov. Y. B, et al, "Methods Of Forming Professional Competence Of Students As Future Teachers", International Journal of Environmental \& Science Education, vol.11 pp. 6651-6662, 2006.

[6] Plomp. T \& Nievenn N, Educational Design Research-Part A: An Introduction. Enschede: Netherland Institute for Curriculum Development (SLO) PQ4R Strategy Accompanied by Refutation Text Reading, 2013.

[7] H. Freudenthal, Revisiting mathematics education. Dordrecht, The Netherlands: Kluwer Academic, 1991. 